Article

\title{
Facile Synthesis of 5-Aryl- $N$-(pyrazin-2-yl)thiophene-2- carboxamides via Suzuki Cross-Coupling Reactions, Their Electronic and Nonlinear Optical Properties through DFT Calculations
}

\author{
Gulraiz Ahmad ${ }^{1}$ (D), Nasir Rasool 1,*, Adeel Mubarik ${ }^{1}$, Ameer Fawad Zahoor ${ }^{1}$ (D), Muhammad Ali Hashmi ${ }^{2}$ (D), \\ Muhammad Zubair ${ }^{1}$, Muhammad Bilal ${ }^{1}$, Mohamed Hussien ${ }^{3}$, Muhammad Saeed Akhtar ${ }^{4}$ (D) \\ and Sajjad Haider $5, *$ (D)
}

check for updates

Citation: Ahmad, G.; Rasool, N.; Mubarik, A.; Zahoor, A.F.; Hashmi, M.A.; Zubair, M.; Bilal, M.; Hussien, M.; Akhtar, M.S.; Haider, S. Facile Synthesis of 5-Aryl- $N$-(pyrazin-2yl)thiophene-2-carboxamides via Suzuki Cross-Coupling Reactions, Their Electronic and Nonlinear Optical Properties through DFT Calculations. Molecules 2021, 26, 7309. https://doi.org/10.3390/ molecules26237309

Academic Editor: Demeter Tzeli

Received: 16 August 2021

Accepted: 7 November 2021

Published: 2 December 2021

Publisher's Note: MDPI stays neutral with regard to jurisdictional claims in published maps and institutional affiliations.

Copyright: (c) 2021 by the authors. Licensee MDPI, Basel, Switzerland. This article is an open access article distributed under the terms and conditions of the Creative Commons Attribution (CC BY) license (https:/ / creativecommons.org/licenses/by/ $4.0 /)$.
1 Department of Chemistry, Government College, University Faisalabad, Faisalabad 38000, Pakistan; gulchemist35@gmail.com (G.A.); adeelmubarik2@gmail.com (A.M.); fawad.zahoor@gmail.com (A.F.Z.); zubairmkn@gcuf.edu.pk (M.Z.); muhammadbilalgcuf@gmail.com (M.B.)

2 Department of Chemistry, University of Education Lahore, Attock Campus, Attock 43600, Pakistan; i4hashmi@hotmail.com

3 Department of Chemistry, Faculty of Science, King Khalid University, P.O. Box 9004, Abha 61413, Saudi Arabia; ma2464013@gmail.com

4 School of Chemical Engineering, Yeungnam University, Gyeongsan 38541, Korea; msakhtar@ynu.ac.kr

5 Chemical Engineering Department, College of Engineering, King Saud University, P.O. Box 800, Riyadh 11421, Saudi Arabia

* Correspondence: nasirrasool@gcuf.edu.pk (N.R.); shaider@ksu.edu.sa (S.H.); Tel.: +92-332-7491790 (N.R.); Fax: +92-41-9201032 (N.R.)

\begin{abstract}
Synthesis of 5-aryl-N-(pyrazin-2-yl)thiophene-2-carboxamides (4a-4n) by a Suzuki crosscoupling reaction of 5-bromo- $N$-(pyrazin-2-yl)thiophene-2-carboxamide (3) with various aryl/heteroaryl boronic acids/pinacol esters was observed in this article. The intermediate compound 3 was prepared by condensation of pyrazin-2-amine (1) with 5-bromothiophene-2-carboxylic acid (2) mediated by $\mathrm{TiCl}_{4}$. The target pyrazine analogs $(\mathbf{4 a}-\mathbf{4 n})$ were confirmed by NMR and mass spectrometry. In DFT calculation of target molecules, several reactivity parameters like FMOs ( $\left.\mathrm{E}_{\mathrm{HOMO}}, \mathrm{E}_{\mathrm{LUMO}}\right), \mathrm{HOMO}$ LUMO energy gap, electron affinity (A), ionization energy (I), electrophilicity index $(\omega)$, chemical softness $(\sigma)$ and chemical hardness $(\eta)$ were considered and discussed. Effect of various substituents was observed on values of the HOMO-LUMO energy gap and hyperpolarizability. The p-electronic delocalization extended over pyrazine, benzene and thiophene was examined in studying the NLO behavior. The chemical shifts of ${ }^{1} \mathrm{H}$ NMR of all the synthesized compounds $\mathbf{4 a}-\mathbf{4} \mathbf{n}$ were calculated and compared with the experimental values.
\end{abstract}

Keywords: pyrazine; thiophenecarboxamide; Suzuki coupling; FMO analysis; NLO properties; ${ }^{1} \mathrm{H}$ NMR comparison

\section{Introduction}

Pyrazine derivatives are a vital group of heterocyclic compounds present in nature and have also been synthesized in laboratories since 1876 [1,2]. Pyrazines and their derivatives play a significant role as intermediates for pharmaceuticals, agricultural chemicals [1], etc. In particular, pyrazine derivatives display a large number of pharmaceutical activities: anticancer [3], diuretic [4], antidiabetic [5] and anti-inflammatory [6]. Various synthetic procedures have been implemented to synthesize these biologically active pyrazine derivatives [7-9]. Naturally, these are found in tobacco, roasted and nut-like flavors and also the taste and fragrance of many foodstuffs [10].

Pyrazine carboxamide analogs like T-705 and T-1105 (Figure 1) are innovative broadspectrum viral polymerase inhibitors against various RNA viruses [11-13]. T-705 is also 
studied in terms of treatment of several viral infections, including SARS-CoV-2 [14]. Pyrazinamide analogs were also studied for their high antimicrobial activity [15]. Pyrazinamide (PZA) is a vital first-line anti-tuberculosis agent and revealed a distinct inhibiting effect $[16,17]$. It contributes an exclusive role in shortening the therapy duration from more than nine months previously to six months as it kills semi-dormant tubercle bacilli in acidic environments compared to other TB drugs [18].<smiles>NC(=O)c1nc(F)cnc1O</smiles>

T-705<smiles>NC(=O)c1nccnc1O</smiles>

T-1105

Figure 1. RNA viral polymerase inhibitors T-705 and T-1105.

In recent years, organic NLO (nonlinear optical) materials have attained great interest due to their remarkable uses in photonics and optoelectronics comprising optical signal processing, optical communications, optical data storage and optoelectronic transfer [19-21]. To display prominent second-order NLO properties, a molecule should be non-centrosymmetric along with intramolecular charge transfer transitions, a large transition dipole moment and a huge difference in the molecular dipole moment at the ground and excited state $[20,22]$. It can be attained in linear organic compounds by substituting electron-donating and withdrawing groups as it happens in conventional organic dipolar push-pull systems [23].

Pyrazine compounds are a rigid planar conjugated structure, have electron-deficient character, and so the pyrazinyl moiety can be used as an electron-withdrawing group in electron push-pull systems [24]. Thus, pyrazine entities incorporation in luminescent materials has been studied recently [25]. Moreover, the electron push-pull pyrazine analogs exhibited fascinating second-order [26-28] and third-order [29-31] NLO properties. Therefore, in this manuscript, we elaborated on the production of a new sequence of 5-aryl- $N$-(pyrazin-2-yl)thiophene-2-carboxamides (4a-4n) and exploration of their NLO properties. We also focused on the structural reactivity parameters and ${ }^{1} \mathrm{H}$ NMR spectra.

\section{Results and Discussion}

\subsection{Chemistry}

The reaction of pyrazine-2-amine (1) with 5-bromothiophene-2-carboxylic acid (2) in the presence of pyridine and titanium tetrachloride was used to produce 5-bromo- $\mathrm{N}$ (pyrazin-2-yl)thiophene-2-carboxamide (3) with 75\% yield, as shown in Scheme 1. Thereafter, compound $\mathbf{3}$ was treated with different aryl boronic acids/pinacol esters by using catalyst $\mathrm{Pd}\left(\mathrm{PPh}_{3}\right)_{4}$, potassium phosphate and solvent 1,4-dioxane. The derivatives of 5-bromo- $N$-(pyrazin-2-yl)thiophene-2-carboxamide ( $\mathbf{4 a -} \mathbf{- 4 n})$ were obtained with moderate and good yields $(37-72 \%)$. The structural representation of these molecules and their yields are provided in Figure 2. Compound 4a showed the maximum yield $(72 \%)$, while compound $4 \mathrm{n}$ exhibited the lowest yield (37\%). The compounds having substitution 3,4dichloro (4b), 3-methylcarbonyl (4c), 4-chloro (4d), 3-cholro4-fluoro (4e), 3,5-dimethyl (4f), 4-methoxy (4g), 4-methylthio (4i) and 3,5-difluoro (4j) were also synthesized with good yields. It was noted that the synthesized molecules obtained from thiophene boronic acid pinacol esters and bulky group substituted phenylboronic acid exhibited a low yield as compared to other molecules. It is noteworthy that the boronic acids and the pinacolate esters having electron-donating moieties provided good yields while the electron-withdrawing moieties provided lower yields [32]. Exceptionally, compound 4a provided a good yield. 


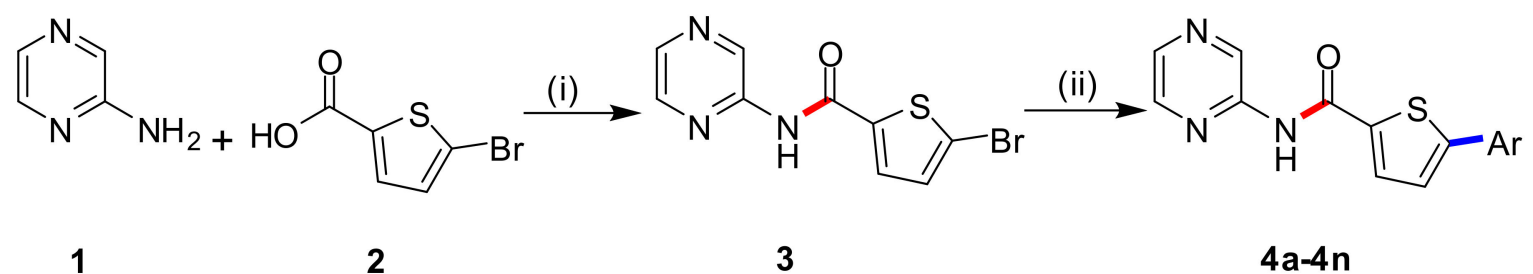

Scheme 1. Synthesis and arylation of 5-bromo- $N$-(pyrazin-2-yl)thiophene-2-carboxamide (3) to form analogs (4a-4n).<smiles>O=C(Nc1cnccn1)c1ccc(-c2cccc(Cl)c2)s1</smiles>

4a $(72 \%)$<smiles>O=C(Nc1cnccn1)c1ccc(-c2ccc(Cl)c(Cl)c2)s1</smiles>

4b $(59 \%)$<smiles>CC(=O)c1cccc(-c2ccc(C(=O)Nc3cnccn3)s2)c1</smiles>

4c $(60 \%)$<smiles>O=C(Nc1cnccn1)c1ccc(-c2ccc(Cl)cc2)s1</smiles><smiles>O=C(Nc1cnccn1)c1ccc(-c2ccc(F)c(Cl)c2)s1</smiles><smiles>Cc1cc(C)cc(-c2ccc(C(=O)Nc3cnccn3)s2)c1</smiles>

4d $(68 \%)$

4 e $\quad(50 \%)$

$4 f \quad(62 \%)$<smiles>COc1ccc(-c2ccc(C(=O)Nc3cnccn3)s2)cc1</smiles>

4 g $(57 \%)$<smiles>COC(=O)c1ccc(-c2ccc(C(=O)Nc3cnccn3)s2)cc1</smiles>

4h $(46 \%)$<smiles>CSc1ccc(-c2ccc(C(=O)Nc3cnccn3)s2)cc1</smiles>

$4 i \quad(52 \%)$<smiles>O=C(Nc1cnccn1)c1ccc(-c2cc(F)cc(F)c2)s1</smiles>

4j (58\%)<smiles>O=C(Nc1cnccn1)c1ccc(-c2ccc(Cl)s2)s1</smiles><smiles>Cc1ccc(-c2ccc(C(=O)Nc3cnccn3)s2)s1</smiles>

4k $\quad(39 \%)$

4I (43\%)<smiles>CC(C)(C)c1ccc(-c2cc(C(F)(F)F)cc(C(F)(F)F)c2)s1</smiles><smiles>O=C(Nc1cnccn1)c1ccc(-c2cc(Cl)cc(C(F)(F)F)c2)s1</smiles>

4 n $(37 \%)$

Figure 2. An overview of 5-bromo- $N$-(pyrazin-2-yl)thiophene-2-carboxamide derivatives via a Suzuki cross-coupling reaction.

\subsection{Computational Details}

In this study, the geometric optimization of the synthesized molecules (4a-4n) followed by the computation of several quantum chemical parameters was studied through density functional theory (DFT) calculations. DFT is a cheap and widely used method for modeling the ground state of molecules. From the computational point of view, these methods have become very popular in recent years because they can attain similar accuracy to the ab initio methods in less time and at a lower computational cost [33]. The optimization 
of the molecules $(\mathbf{4 a} \mathbf{a}-\mathbf{4 n})$ was accomplished with the PBE0-D3BJ/def2-TZVP/SMD 1 ,4-dioxane level of theory [34] which is widely used for providing accurate geometries and electronic properties for a large number of molecules. The solvent model density (SMD) is a polarizable continuum model that includes the full solute electron density without defining partial atomic charges. It is a universal solvation model, which means that it can be applied to any kind of molecules. [35]. Frequency calculations were performed on the optimized structures to confirm the obtained geometries as true minima by the absence of imaginary frequencies. The optimized structures were further used for molecular electrostatic potential (MESP) and frontier molecular orbital (FMO) analysis on the same level of theory. Chemical reactivity is defined as the tendency of a substance to react chemically with another substance. Reactivity parameters such as electron affinity, ionization energy, chemical softness and hardness, electrophilicity and chemical potential were also calculated. Modeling of the synthesized molecules (4a-4n) was performed using GaussView 6 [36] and the calculations were performed using the Gaussian 09 [37] program.

\subsubsection{Optimized Geometries}

In the field of computational chemistry, geometries optimization is a crucial process to find the ground state geometry of molecules that can be used to compute other properties [38]. In the case of conformationally flexible compounds, a conformational search is crucial to find out the minimum energy conformers that must be used to compute all the other properties. A relaxed potential energy scan was performed considering the important dihedrals, and low-energy conformers were selected from the resultant potential energy scan (PES) followed by geometry optimization and removal of duplicates. These conformers were then subjected to the properties calculations like NMR and Boltzmann averaging of the results was performed afterwards. The Boltzmann-averaged values are provided in the respective tables that show a very good agreement with the experimental data. The optimized geometries of the most stable conformers of the molecules $(\mathbf{4 a}-\mathbf{4 n})$ calculated at the PBE0-D3BJ/def2-TZVP/SMD 1,4 -dioxane level of theory are provided in Figure 3. All the PES figures are provided in the Supplementary Materials.

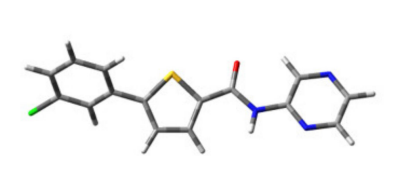

$4 \mathbf{a}$

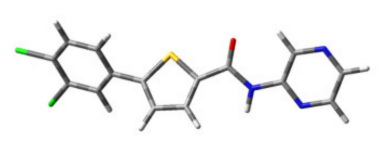

4b<smiles>CC1CCC(C)C(C(C)C(C)C(C)C2C(C)CCC2C)C1</smiles>

$4 c$

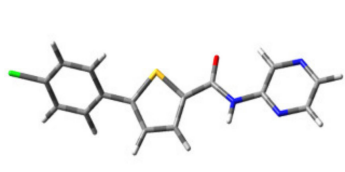

4d

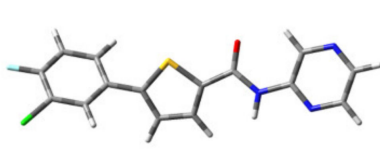

$4 e$

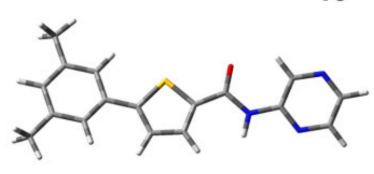

4f

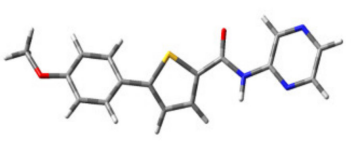

$4 \mathrm{~g}$

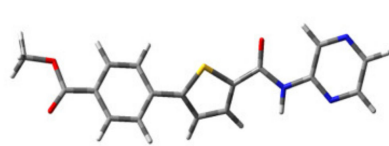

4h

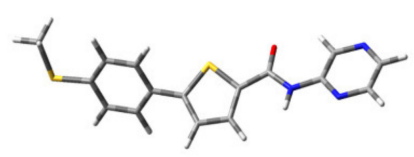

$4 \mathbf{i}$

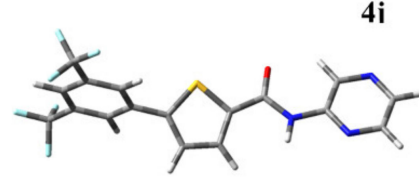

$4 m$

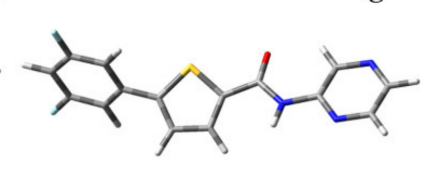

$4 i$

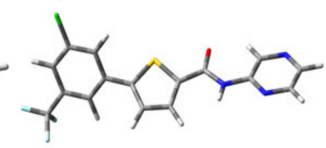

4n

Figure 3. Optimized structures of all the final derivatives (4a-4n). In the 3D models, the yellow color indicates $\mathrm{S}$, the red color represents oxygen, the grey color indicates $\mathrm{C}$, the green color is for $\mathrm{Cl}$, the light blue color shows $\mathrm{F}$ and the white color symbolizes $\mathrm{H}$. 


\subsubsection{Nuclear Magnetic Resonance Spectroscopy (NMR)}

NMR is the most important technique for determining the accurate structure of organic compounds. Quantum calculations are found to be sufficiently accurate in calculating NMR spectra and studying the relationship between the molecular structure and its chemical shifts. Therefore, the use of theoretical methods is very useful for augmenting the confidence in explaining the structure of molecules [39-41]. In this study, the experimental ${ }^{1} \mathrm{H}$ spectra (4a-4n) were recorded in 1,4-dioxane while the calculation of the ${ }^{1} \mathrm{H}$ and ${ }^{13} \mathrm{C}$ NMR spectra was performed using the same level of theory as for the optimizations. The comparison of the experimental and theoretical calculated ${ }^{1} \mathrm{H}$ NMR data of compound $4 \mathbf{a}$ is provided in Table 1 while the ${ }^{1} \mathrm{H}$ NMR data of the remaining compounds $4 \mathbf{b}-\mathbf{4 n}$ are provided in the Supplementary Materials (Tables S1-S13). It can be seen that the performance of the NMR calculations was very good and the mean absolute error (MAE) is only $0.25 \mathrm{ppm}$.

Table 1. Comparison of the experimental and theoretical ${ }^{1} \mathrm{H}$ NMR data of compound 4a. The data for the rest of the compounds is provided in the Supplementary Materials. The mean absolute deviation is presented as the mean absolute error and, similarly, the root-mean-square deviation is denoted as the root-mean-square error.

\begin{tabular}{ccccc}
\hline \multicolumn{5}{c}{ Compound 4a } \\
\hline Carbon No. & Carbon Type & $\begin{array}{c}\mathbf{1}^{\mathbf{H}} \mathbf{N M R}(\boldsymbol{\delta}, \mathbf{p p m}), \\
\text { Experimental }\end{array}$ & $\begin{array}{c}\mathbf{1}^{\mathbf{H}} \mathbf{N M R}(\boldsymbol{\delta}, \mathbf{p p m}), \\
\text { Computed }\end{array}$ & $\mathbf{\Delta} \boldsymbol{\delta}, \mathbf{p p m}$ \\
\hline 2 & $\mathrm{C}$ & - & - & - \\
3 & $\mathrm{CH}$ & 9.39 & 10.55 & -1.16 \\
4 & $\mathrm{~N}$ & - & - & - \\
5 & $\mathrm{CH}$ & 8.45 & 8.43 & 0.02 \\
6 & $\mathrm{CH}$ & 8.45 & 8.42 & 0.03 \\
$2^{\prime}$ & $\mathrm{C}$ & - & - & - \\
$3^{\prime}$ & $\mathrm{CH}$ & 7.84 & 7.24 & 0.60 \\
$4^{\prime}$ & $\mathrm{CH}$ & 7.72 & - & 0.92 \\
$5^{\prime}$ & $\mathrm{C}$ & - & - & - \\
$1^{\prime \prime}$ & $\mathrm{C}$ & - & 7.45 & - \\
$2^{\prime \prime}$ & $\mathrm{CH}$ & 8.26 & - & 0.81 \\
$3^{\prime \prime}$ & $\mathrm{C}$ & - & 7.37 & - \\
$4^{\prime \prime}$ & $\mathrm{CH}$ & 7.50 & 7.39 & 0.13 \\
$5^{\prime \prime}$ & $\mathrm{CH}$ & 7.45 & 7.25 & 0.06 \\
$6^{\prime \prime}$ & $\mathrm{CH}$ & 7.70 & & 0.45 \\
\hline
\end{tabular}

Mean absolute error $(\mathrm{MAE})=0.17$; root-mean-square error $(\mathrm{RMSE})=0.37$.

\subsubsection{FMO and NLO Analysis}

The frontier molecular orbitals (FMO) of a compound are the highest occupied molecular orbitals (HOMO) and the lowest unoccupied molecular orbitals (LUMO). Logically, the HOMO are regarded as electron-donating or nucleophilic while the LUMO are regarded as electron-accepting or electrophilic. In addition, chemical reactions and resonances on one or more molecules can be described by overlapping between the filled HOMOs and empty LUMOs. These basic ideas are used in the FMO theory to elucidate the structure and reactivity of compounds. To determine the chemical stability and reactivity of the molecules, the HOMO-LUMO and their energy gap are very important quantum chemical parameters. These MO also have the key role in determining optical and electrical properties.

The molecular orbitals of all the compounds $4 \mathbf{a}-4 \mathbf{n}$ have almost the same pattern but some compounds have a different one. In most of the compounds, the density of molecular orbitals is mostly spread over the thiophene and benzene rings, but there are some compounds in which the density of molecular orbitals also spreads over the pyrazine ring. A plot of these surfaces is displayed in Figure 4. 


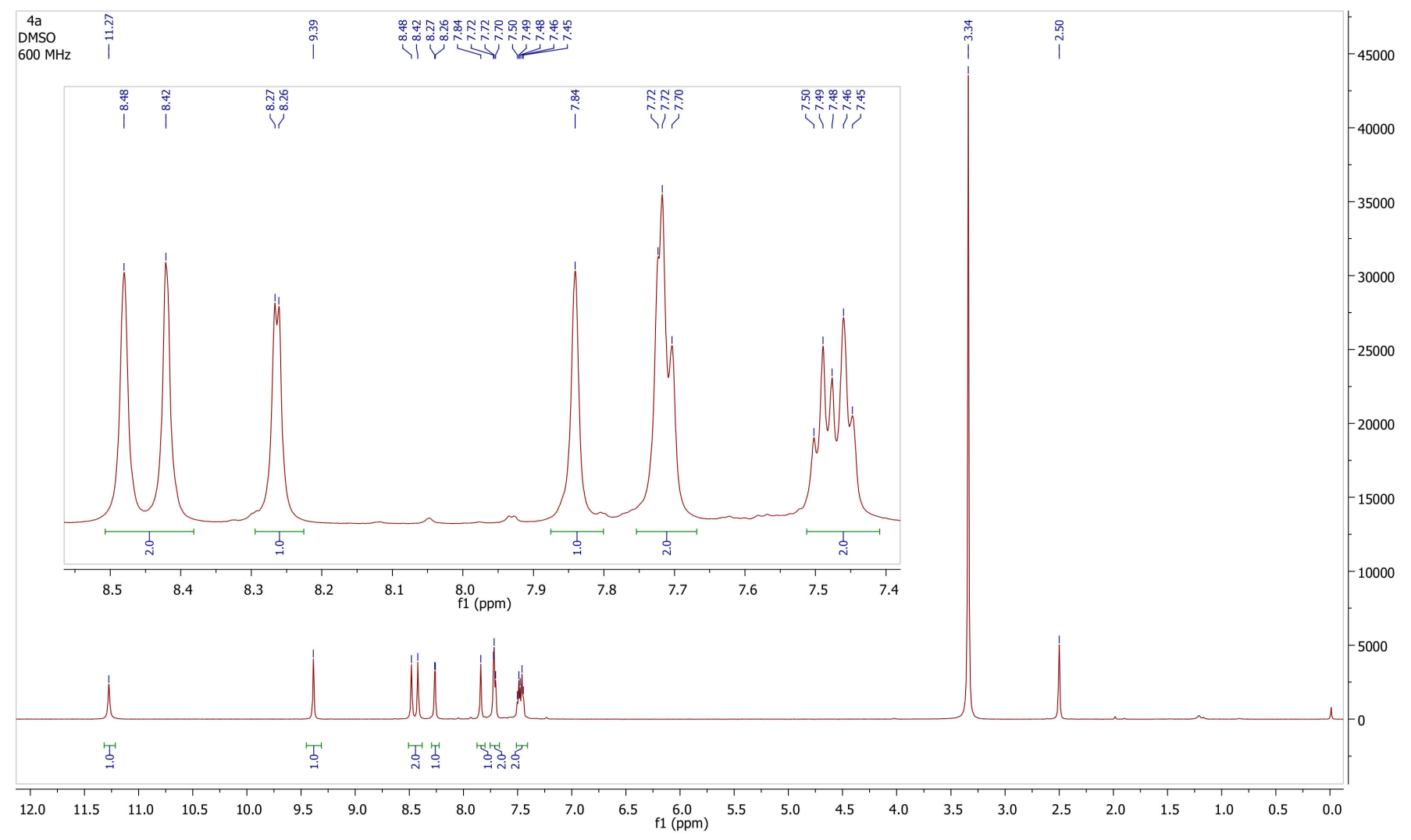

Figure 4. ${ }^{1} \mathrm{H}$ NMR spectra of compound 4a at $600 \mathrm{MHz}$.

The highest HOMO-LUMO energy gap shows that the compound is the most stable and the least reactive and the lowest energy gap shows that the compound is the least stable and the most reactive [42-44].

In this series $(\mathbf{4 a}-\mathbf{4 n})$, it was observed that compound $4 \mathrm{~m}$ consisting of three rings (pyrazine, benzene and thiophene) with two $\mathrm{CF}_{3}$ substituents and compound $4 \mathbf{j}$ consisting of three rings (pyrazine, benzene and thiophene) with two fluoride substituents have the highest HOMO-LUMO energy gap of 4.93 and $4.89 \mathrm{eV}$, respectively, which shows that both these compounds are the most stable and the least reactive in this series. Compound $4 \mathbf{i}$ consisting of three rings (pyrazine, benzene and thiophene) with an $\mathrm{SH}$ substituent has the lowest HOMO-LUMO energy gap of $4.21 \mathrm{eV}$ which shows that it is the least stable one with the highest reactivity. All the other compounds have a HOMO-LUMO energy gap in the range of 4.21-4.93 eV. The values of HOMO and LUMO energies and their energy gap $(\Delta \mathrm{E})$ along with their polarizability $(\alpha)$ and hyperpolarizability $(\beta)$ of all the compounds $\mathbf{4 a}-\mathbf{4 n}$ are provided in Table 2.

Table 2. Energies of the HOMO, LUMO, HOMO-LUMO energy gap, polarizability $(\alpha)$ and hyperpolarizability ( $\beta \mathrm{o}$ ) values of compounds $\mathbf{4 a}-\mathbf{4 n}$.

\begin{tabular}{cccccc}
\hline Compounds & E $_{\text {HOMO }}(\mathbf{e V})$ & E $_{\text {LUMO }}(\mathbf{e V})$ & $\mathrm{E}_{\text {LUMO }}-\mathrm{E}_{\text {HOMO }}(\mathrm{eV})$ & $\boldsymbol{\alpha}$ (a.u.) & $\beta$ o (a.u.) \\
\hline $\mathbf{4 a}$ & -6.781 & -1.958 & 4.823 & 310.96 & 2700.54 \\
$\mathbf{4 b}$ & -6.770 & -2.006 & 4.763 & 325.22 & 4139.08 \\
$\mathbf{4 c}$ & -6.771 & -2.008 & 4.763 & 338.09 & 2571.25 \\
$\mathbf{4 d}$ & -6.702 & -1.914 & 4.788 & 311.83 & 3958.52 \\
$\mathbf{4 e}$ & -6.756 & -1.973 & 4.784 & 310.60 & 4004.42 \\
$\mathbf{4 f}$ & -6.345 & -2.005 & 4.340 & 354.10 & 6120.41 \\
$\mathbf{4 g}$ & -6.229 & -1.770 & 4.459 & 330.84 & 8398.11 \\
\hline
\end{tabular}


Table 2. Cont.

\begin{tabular}{cccccc}
\hline Compounds & $\mathbf{E}_{\text {HOMO }}(\mathbf{e V})$ & $\mathbf{E}_{\text {LUMO }}(\mathbf{e V})$ & $\mathrm{E}_{\text {LUMO }}-\mathrm{E}_{\text {HOMO }}(\mathbf{e V})$ & $\boldsymbol{\alpha}$ (a.u.) & $\beta$ 及o (a.u.) \\
\hline $\mathbf{4 h}$ & -6.818 & -2.082 & 4.736 & 345.57 & 1363.79 \\
$\mathbf{4 i}$ & -6.027 & -1.815 & 4.212 & 349.43 & 9139.57 \\
$\mathbf{4} \mathbf{j}$ & -6.870 & -1.977 & 4.893 & 293.78 & 1926.82 \\
$\mathbf{4} \mathbf{k}$ & -6.475 & -2.103 & 4.373 & 310.21 & 6520.24 \\
$\mathbf{4}$ & -6.231 & -2.000 & 4.231 & 325.48 & 9048.28 \\
$\mathbf{4} \mathbf{m}$ & -6.985 & -2.048 & 4.937 & 315.57 & 1103.20 \\
$\mathbf{4 n}$ & -6.919 & -2.113 & 4.806 & 322.84 & 1416.47 \\
\hline
\end{tabular}

Through experimental and theoretical methods, organic nonlinear optical (NLO) materials have been widely studied to explore their potential applications in optical signal processing, telecommunications and optical data storage. Theoretical research may contribute the key role in understanding the origin of molecular NLO properties and predicting the relationship between the structure and the NLO properties, which is the basis for the design and production of new materials [45]. Most organic compounds with pi-conjugated systems are mainly suitable for the expansion of the NLO material because, among other features, they show large nonlinearity which is due to electronic polarizability.

In this series $(\mathbf{4 a}-\mathbf{4 n})$, compounds $\mathbf{4 i}$ and $\mathbf{4 1}$ have the highest hyperpolarizability values of 9139.57 a.u. and 9048.28 a.u., respectively, showing the highest NLO responses, while the remaining compounds show very small hyperpolarizability values. Our research group reported $\mathrm{N}$-heterocyclic derivatives having smaller values of hyperpolarizability as compared to the compounds in this study $(\mathbf{4 a}-\mathbf{4 n})$ [34].

\subsubsection{Molecular Electrostatic Potential (MESP) Analysis}

In recent years, the maps of molecular electrostatic potential have been extensively used to recognize the reactive sites for nucleophilic and electrophilic attacks during chemical reactions, the study of $\mathrm{H}$-bond interactions and the biological recognition process. MESP is related to the distribution of the total charge of a compound and provides information about some physical properties of the molecules such as partial charges of the atoms, electronegativity, chemical reactivity and dipole moment. In the MESP diagram, different electrostatic potential values on the surface are shown with different colors. The most positive electrostatic potential area is shown in blue, the most negative electrostatic potential area is shown in red, and green is the zero potential area [46-48].

In the maps of the MESP of compounds $4 \mathbf{a}-\mathbf{4 n}$ (Figure 5), the red color shows that the most negative ESP regions are mainly located over the oxygen of the carbonyl group, which is a suitable position for the attack of electrophiles while the blue color shows that the most positive ESP regions are mainly located over the hydrogen of the amide group, which is a suitable position for the attack of nucleophiles. The maps of the MESP of compounds $\mathbf{4 a}-\mathbf{4 n}$ are provided in Figure 6.

\subsubsection{Reactivity Descriptors}

Chemical reactivity is the key concept because it is closely related to the reaction mechanism so chemical reactions can be understood and synthetic procedures can be improved to obtain new materials. The ionization potential $\left(\mathrm{I}=-\mathrm{E}_{\mathrm{HOMO}}\right)$ and electron affinity $\left(\mathrm{A}=-\mathrm{E}_{\mathrm{LUMO}}\right)$ were calculated using Koopman's theorem [49] as well as directly and a comparison is provided in Table 3. 


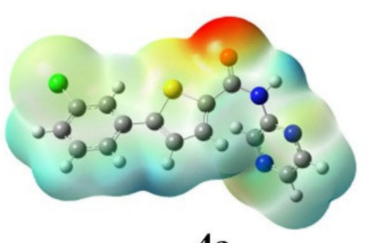

$4 a$

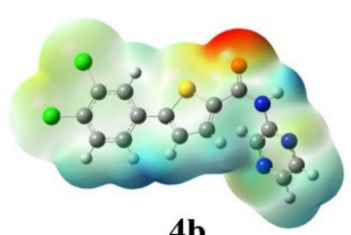

4b

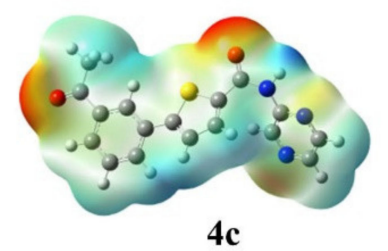

4c

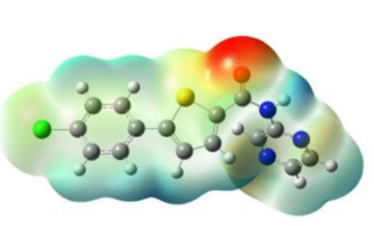

4d

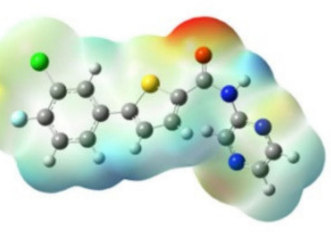

$4 e$

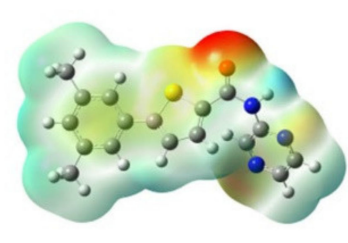

4f

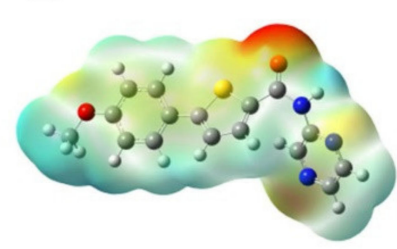

$4 \mathrm{~g}$

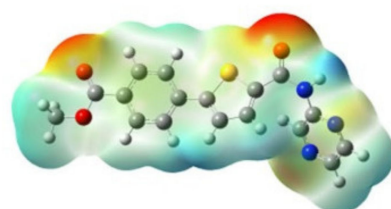

$4 h$

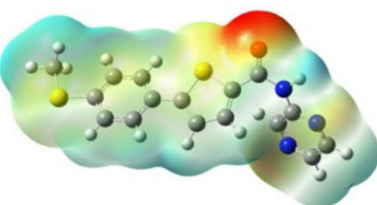

$4 \mathbf{i}$

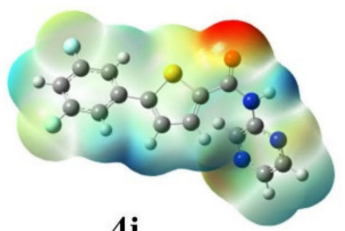

$4 j$

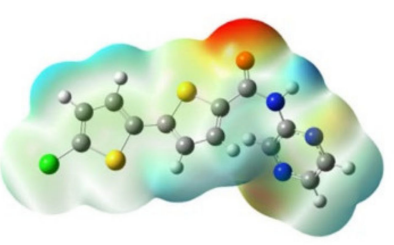

$4 \mathbf{k}$

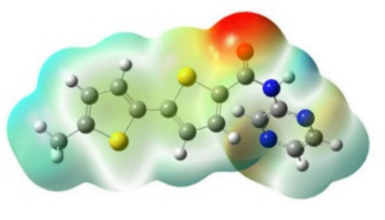

41

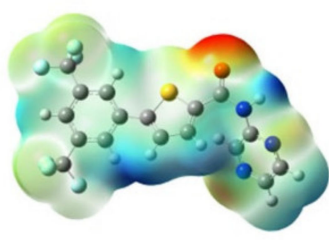

$4 m$

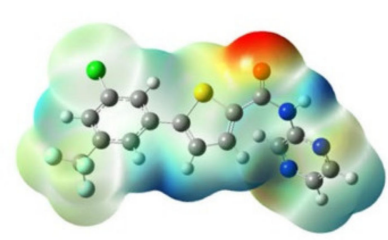

4n

Figure 5. Molecular electrostatic potential surfaces of the final compounds $4 \mathbf{a}-\mathbf{4 n}$ computed at the PBE0-D3BJ/def2$\mathrm{TZVP} / \mathrm{SMD}_{1,4-\text { dioxane }}$ level of theory. The units for the scale are atomic units.

The electronic chemical potential $(\mu)$ and molecular hardness $(\eta)$ have been proposed to measure global reactivity $[50,51]$. Chemical potential $(\mu)$ describes the charge transfer at the ground state within the compound. The electrophilicity index $(\omega)$ is a thermodynamic characteristic that calculates the energy changes of a saturated chemical system after the addition of electrons. It plays an important role in determining the chemical reactivity of a system. The values of $\eta, \sigma, \mu$ and $\omega$ were calculated using the following Equations (1)-(4) [52] and are mentioned in Table 4.

$$
\begin{gathered}
\text { Chemical hardness }(\eta)=(I-A) / 2 \\
\text { Chemical softness }(\sigma)=1 / \eta
\end{gathered}
$$

Chemical potential $(\mu)=-(\mathrm{I}+\mathrm{A}) / 2$

Electrophilicity index $(\omega)=\mu^{2} / 2 \eta$ 


\begin{tabular}{|c|c|c|c|c|c|}
\hline Compound & HOMO (\†) & LUMO (_) & Compound & 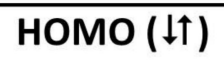 & LUMO (_) \\
\hline $4 a$ & $-6.781 \mathrm{eV}$ & $-1.958 \mathrm{eV}$ & $4 b$ & $-6.770 \mathrm{eV}$ & $\begin{array}{l}-2.006 \mathrm{eV} \\
\end{array}$ \\
\hline $4 c$ & $-6.771 \mathrm{eV}$ & $-2.008 \mathrm{eV}$ & $4 d$ & $-6.702 \mathrm{eV}$ & $-1.914 \mathrm{eV}$ \\
\hline $4 e$ & $-6.756 \mathrm{eV}$ & $-1.973 \mathrm{eV}$ & $4 f$ & $-6.345 \mathrm{eV}$ & $-2.005 \mathrm{eV}$ \\
\hline $4 g$ & $-6.229 \mathrm{eV}$ & $-1.770 \mathrm{eV}$ & $4 h$ & $-6.818 \mathrm{eV}$ & $-2.082 \mathrm{eV}$ \\
\hline $4 i$ & $-6.027 \mathrm{eV}$ & $-1.815 \mathrm{eV}$ & $4 j$ & $-6.870 \mathrm{eV}$ & $-1.977 \mathrm{eV}$ \\
\hline $4 k$ & $-6.475 \mathrm{eV}$ & $-2.103 \mathrm{eV}$ & 41 & $-6.231 \mathrm{eV}$ & $-2.000 \mathrm{eV}$ \\
\hline $4 m$ & $-6.985 \mathrm{eV}$ & $-2.048 \mathrm{eV}$ & $4 n$ & $-6.919 \mathrm{eV}$ & $-2.113 \mathrm{eV}$ \\
\hline
\end{tabular}

Figure 6. FMO surfaces of compounds $4 \mathbf{a}-\mathbf{4 n}$ computed at the PBE0-D3BJ/def2-TZVP/SMD 1 4-dioxane level of theory.

Table 3. Ionization potential (I) and electron affinity (A) of compounds $\mathbf{4 a}-\mathbf{4 n}$ calculated through Koopman's theorem and directly, i.e., through optimization of charged molecules.

\begin{tabular}{ccccc}
\hline \multirow{2}{*}{ Compounds } & \multicolumn{2}{c}{$\begin{array}{c}\text { Calculated through Koopman's } \\
\text { Theorem }\end{array}$} & \multicolumn{2}{c}{$\begin{array}{c}\text { Calculated Directly from Charged } \\
\text { Molecules }\end{array}$} \\
\cline { 2 - 5 } & $\mathbf{I ~ ( e V )}$ & $\mathbf{A ~ ( e V )}$ & $\mathbf{I ~ ( e V )}$ & $\mathbf{A ~ ( e V )}$ \\
\hline $\mathbf{4 a}$ & 6.78 & 1.96 & 6.16 & 0.47 \\
$\mathbf{4 b}$ & 6.77 & 2.01 & 6.23 & 0.50 \\
$\mathbf{4} \mathbf{4}$ & 6.77 & 2.01 & 7.19 & 0.06 \\
$\mathbf{4}$ & 6.70 & 1.91 & 6.16 & 0.44 \\
$\mathbf{4}$ & 6.76 & 1.97 & 6.23 & 0.50 \\
\hline
\end{tabular}


Table 3. Cont.

\begin{tabular}{ccccc}
\hline \multirow{2}{*}{ Compounds } & \multicolumn{2}{c}{$\begin{array}{c}\text { Calculated through Koopman's } \\
\text { Theorem }\end{array}$} & \multicolumn{2}{c}{$\begin{array}{c}\text { Calculated Directly from Charged } \\
\text { Molecules }\end{array}$} \\
\cline { 2 - 5 } & $\mathbf{I ~ ( e V )}$ & $\mathbf{A ~ ( e V )}$ & $\mathbf{I ~ ( e V )}$ & $\mathbf{A ~ ( e V )}$ \\
\hline $\mathbf{4 f}$ & 6.35 & 2.00 & 5.75 & 0.83 \\
$\mathbf{4 g}$ & 6.23 & 1.77 & 5.88 & 0.28 \\
$\mathbf{4} \mathbf{h}$ & 6.82 & 2.08 & 7.20 & 0.42 \\
$\mathbf{4 i}$ & 6.03 & 1.81 & 5.67 & 0.37 \\
$\mathbf{4 j}$ & 6.87 & 1.98 & 7.29 & 0.52 \\
$\mathbf{4} \mathbf{k}$ & 6.48 & 2.10 & 6.21 & 0.75 \\
$\mathbf{4 1}$ & 6.23 & 2.00 & 5.79 & 0.73 \\
$\mathbf{4} \mathbf{m}$ & 6.99 & 2.05 & 6.61 & 0.58 \\
$\mathbf{4 n}$ & 6.92 & 2.11 & 6.36 & 0.60 \\
\hline
\end{tabular}

Table 4. Reactivity descriptors $\eta, \sigma, \mu$ and $\omega$ values of the final compounds $4 \mathbf{a}-\mathbf{4 n}$.

\begin{tabular}{ccccc}
\hline Compounds & $\boldsymbol{\eta} \mathbf{( e V )}$ & $\boldsymbol{\sigma}\left(\mathbf{e V}^{-\mathbf{1}}\right)$ & $\boldsymbol{\mu}(\mathbf{e V})$ & $\boldsymbol{\omega}(\mathbf{e V})$ \\
\hline $\mathbf{4 a}$ & 2.84 & 0.35 & -3.31 & 1.93 \\
$\mathbf{4 b}$ & 2.86 & 0.34 & -3.36 & 1.97 \\
$\mathbf{4} \mathbf{c}$ & 3.56 & 0.28 & -3.62 & 1.84 \\
$\mathbf{4 d}$ & 2.86 & 0.34 & -3.30 & 1.90 \\
$\mathbf{4} \mathbf{e}$ & 2.86 & 0.34 & -3.36 & 1.97 \\
$\mathbf{4} \mathbf{f}$ & 2.46 & 0.40 & -3.29 & 2.20 \\
$\mathbf{4} \mathbf{g}$ & 2.80 & 0.35 & -3.08 & 1.69 \\
$\mathbf{4} \mathbf{4}$ & 3.39 & 0.29 & -3.81 & 2.14 \\
$\mathbf{4}$ & 2.65 & 0.37 & -3.02 & 1.72 \\
$\mathbf{4} \mathbf{j}$ & 3.38 & 0.29 & -3.90 & 2.25 \\
$\mathbf{4 k}$ & 2.73 & 0.36 & -3.48 & 2.21 \\
$\mathbf{4 1}$ & 2.53 & 0.39 & -3.26 & 2.10 \\
$\mathbf{4} \mathbf{m}$ & 3.01 & 0.33 & -3.59 & 2.14 \\
$\mathbf{4 n}$ & 2.88 & 0.34 & -3.48 & 2.10 \\
\hline
\end{tabular}

The lowest values of ionization energy $(5.67 \mathrm{eV})$ and electron affinity $(0.06 \mathrm{eV})$ of compounds $4 \mathbf{i}$ and $4 \mathbf{c}$ mentioned in Table 4 endorse their high reactivity and lowest stability in series $\mathbf{4 a}-\mathbf{4 n}$.

Among all the derivatives, $4 \mathrm{f}$ has the lowest value of $\eta(2.46 \mathrm{eV})$ and the highest value of $\sigma(0.40)$; thus, it is chemically soft (more reactive), whereas $4 \mathbf{c}$ has the highest value of $\eta$ $(3.56 \mathrm{eV})$ and the lowest value of $\sigma(0.28 \mathrm{eV})$ and is a chemically hardest compound (less reactive). These results correlate with the HOMO-LUMO energy gaps of all the synthesized compounds.

Compound $4 \mathbf{i}$ has the highest electronic chemical potential value $(-3.02 \mathrm{eV})$ while $4 \mathbf{j}$ has the lowest chemical potential value $(-3.90 \mathrm{eV})$. The results indicate that $\mathbf{4 g}$ has the lowest electrophilicity index value of $1.69 \mathrm{eV}$ and has nucleophilic nature, whereas $4 \mathbf{j}$ has the highest value, $2.25 \mathrm{eV}$, and has a strongly electrophilic nature.

\section{Materials and Methods}

\subsection{General Information}

All the chemicals were purchased from Sigma-Aldrich (Burlington, MA, USA), and commercial-grade solvents were used. Melting points of the synthesized compounds were checked with a Buchi B-540 melting point apparatus (New Castle, DE, USA). A Bruker NMR spectrophotometer (Billerica, MA, USA) was used to attain NMR spectra by using DMSO- $d_{6}$ and $\mathrm{CDCl}_{3}$ solvents. Mass spectra were generated on a JEOL spectrometer JMS-HX-110 (USA). To monitor the reaction's progress, TLC on silica gel $60 \mathrm{PF}_{254}$ cards (Merck, Kenilworth, NJ, USA) was used. UV light (254-365 nm) was used to visualize the product on TLC. For the purification of compounds, silica gel (70-230 mesh) was used in columns. 


\subsection{Synthetic Procedure for 5-Bromo-N-(pyrazin-2-yl)thiophene-2-carboxamide (3)}

$\mathrm{TiCl}_{4}(3.0$ eq., $43.47 \mathrm{mmol}, 4.78 \mathrm{~mL}$ ) and pyrazin-2-amine (1) (1 eq., $14.49 \mathrm{mmol}, 1.378 \mathrm{~g})$ were mixed in a solution of 5-bromothiophene-2-carboxylic acid (2) (1 eq., $14.49 \mathrm{mmol}, 3 \mathrm{~g}$ ) and pyridine $(150 \mathrm{~mL})$. The reaction mixture in a sealed schlenk flask was continuously stirred for $2 \mathrm{~h}$ at $85^{\circ} \mathrm{C}$. After cooling, pyridine was separated by coevaporation with toluene. Then, an aqueous solution of $1 \mathrm{~N} \mathrm{HCl}(150 \mathrm{~mL})$ was added and removed with $\mathrm{DCM}(3 \times 150 \mathrm{~mL})$. A saturated aqueous solution of $\mathrm{NaHCO}_{3}(3 \times 150 \mathrm{~mL})$ was used to wash the combined organic layers, dried by anhydrous sodium sulfate and evaporated on a rotary evaporator. The final product was obtained after column chromatography (n-hexane/ethyl acetate, 90:10) with 75\% yield [53,54].

\subsection{Synthetic Procedure for 5-Aryl-N-(pyrazin-2-yl)thiophene-2-carboxamide (4a-4n)}

In an oven-dried schlenk flask, a 1,4-dioxane $(8 \mathrm{~mL})$ solvent, 5-bromo- $\mathrm{N}$-(pyrazin-2yl)thiophene-2-carboxamide (3) (1 eq., $0.704 \mathrm{mmol}, 0.2 \mathrm{~g}$ ) with tetrakis(triphenylphosphine)palladium $(7 \mathrm{~mol} \%, 0.057 \mathrm{~g})$ were added at room temperature, and inert atmosphere was applied. After stirring the reaction for half an hour, boronic acid/pinacol esters (1.1 eq., $0.774 \mathrm{mmol})$, potassium phosphate (2 eq., $1.408 \mathrm{mmol}, 0.297 \mathrm{~g})$ and water $(2 \mathrm{~mL})$ were added [55-57]. The mixture was kept on stirring at reflux for more than $20 \mathrm{~h}$. After cooling to normal temperature, the reaction mixture was filtered with solvent ethyl acetate and then concentrated under reduced pressure. The resulted products were purified with column chromatography (n-hexane/ethyl acetate, 75:25) [58-63]. The final products (4a-4n) were dried, recrystallized and finally analyzed with NMR and mass spectrometry. The NMR spectra of the synthesized compounds are provided in the Supplementary Materials.

\subsection{Characterization Data}

Compound 5-bromo- $\mathrm{N}$-(pyrazin-2-yl)thiophene-2-carboxamide (3). Off-white solid, $\mathrm{MP}=224-226{ }^{\circ} \mathrm{C}(75 \%$ yield, $3.3 \mathrm{~g}) .{ }^{1} \mathrm{H}$ NMR $\left(400 \mathrm{MHz}, \mathrm{CDCl}_{3}\right): \delta 9.62(\mathrm{~s}, 1 \mathrm{H}), 8.40(\mathrm{~s}$, $1 \mathrm{H}), 8.29(\mathrm{~d}, J=11.3 \mathrm{~Hz}, 2 \mathrm{H}), 7.46(\mathrm{~d}, J=3.9 \mathrm{~Hz}, 1 \mathrm{H}), 7.14(\mathrm{~d}, J=3.8 \mathrm{~Hz}, 1 \mathrm{H}) ;{ }^{13} \mathrm{C} \mathrm{NMR}$ $\left(100 \mathrm{MHz}, \mathrm{CDCl}_{3}\right): \delta 159.0,151.1,150.6,147.0,140.5,130.9,128.8,121.4,119.8,115.2,21.5$. EI/MS m/z (\%): $285.1[\mathrm{M}+\mathrm{H}]^{+} ; 286.1[\mathrm{M}+2] ;[\mathrm{M}-\mathrm{Br}]=204.0$. Analitically calculated for $\mathrm{C}_{9} \mathrm{H}_{6} \mathrm{BrN}_{3} \mathrm{OS}: \mathrm{C}, 38.04 ; \mathrm{H}, 2.13 ; \mathrm{N}, 14.79$. Found: $\mathrm{C}, 38.11 ; \mathrm{H}, 2.15 ; \mathrm{N}, 14.74$.

Compound 5-(3-chlorophenyl)- $N$-(pyrazin-2-yl)thiophene-2-carboxamide (4a). Light yellow solid, $\mathrm{MP}=187-189^{\circ} \mathrm{C}(72 \%$ yield, $160 \mathrm{mg}) .{ }^{1} \mathrm{H}$ NMR $\left(600 \mathrm{MHz}\right.$, DMSO- $\left.d_{6}\right): \delta 11.27$ $(\mathrm{s}, 1 \mathrm{H}), 9.39(\mathrm{~s}, 1 \mathrm{H}), 8.45(\mathrm{~d}, J=35.5 \mathrm{~Hz}, 2 \mathrm{H}), 8.26(\mathrm{~d}, J=3.4 \mathrm{~Hz}, 1 \mathrm{H}), 7.84(\mathrm{~s}, 1 \mathrm{H}), 7.72-7.70$ $(\mathrm{m}, 2 \mathrm{H}), 7.50-7.45(\mathrm{~m}, 2 \mathrm{H}) ;{ }^{13} \mathrm{C}$ NMR $\left(151 \mathrm{MHz}\right.$, DMSO- $\left.d_{6}\right): \delta 160.14,148.72,147.66,142.53$, 139.98, 138.25, 137.31, 134.81, 134.04, 131.86, 131.12, 128.55, 125.90, 125.32, 124.60. EI/MS $\mathrm{m} / z(\%): 316.8[\mathrm{M}+\mathrm{H}]^{+} ;[\mathrm{M}-\mathrm{Cl}]=280.1$. Analitically calculated for $\mathrm{C}_{15} \mathrm{H}_{10} \mathrm{ClN}_{3} \mathrm{OS}: \mathrm{C}, 57.05$; $\mathrm{H}, 3.19 ; \mathrm{N}, 13.31$. Found: C, 57.09; H, 3.22; N, 13.26.

Compound 5-(3,4-dichlorophenyl)- $N$-(pyrazin-2-yl)thiophene-2-carboxamide (4b). Off-white solid, MP $=191-193{ }^{\circ} \mathrm{C}(59 \%$ yield, $146 \mathrm{mg}) .{ }^{1} \mathrm{H}$ NMR $\left(600 \mathrm{MHz}, \mathrm{DMSO}-\mathrm{d}_{6}\right): \delta$ $11.27(\mathrm{~s}, 1 \mathrm{H}), 9.38(\mathrm{~s}, 1 \mathrm{H}), 8.47(\mathrm{~s}, 1 \mathrm{H}), 8.42(\mathrm{~d}, J=2.2 \mathrm{~Hz}, 1 \mathrm{H}), 8.25(\mathrm{~d}, J=3.9 \mathrm{~Hz}, 1 \mathrm{H}), 8.03(\mathrm{~d}$, $J=1.5 \mathrm{~Hz}, 1 \mathrm{H}), 7.74-7.69(\mathrm{~m}, 3 \mathrm{H}) ;{ }^{13} \mathrm{C}$ NMR $\left(151 \mathrm{MHz}, \mathrm{DMSO}-d_{6}\right): \delta 160.05,148.68,146.47$, 142.51, 140.00, 138.63, 137.29, 133.38, 132.07, 131.84, 131.31, 131.18, 127.32, 126.36, 125.99 . EI/MS m/z (\%): $351.2[\mathrm{M}+\mathrm{H}]^{+} ;[\mathrm{M}-2 \mathrm{Cl}]=279.3$. Analitically calculated for $\mathrm{C}_{15} \mathrm{H}_{9} \mathrm{Cl}_{2} \mathrm{~N}_{3} \mathrm{OS}$ : C, 51.44; H, 2.59; N, 12.00. Found: C, 51.47; H, 2.62; N, 11.92 .

Compound 5-(3-acetylphenyl)- $\mathrm{N}$-(pyrazin-2-yl)thiophene-2-carboxamide (4c). Light brown solid, $\mathrm{MP}=171-173{ }^{\circ} \mathrm{C}(60 \%$ yield, $137 \mathrm{mg}) .{ }^{1} \mathrm{H}$ NMR $\left(600 \mathrm{MHz}, \mathrm{DMSO}-d_{6}\right): \delta$ $11.25(\mathrm{~s}, 1 \mathrm{H}), 9.42(\mathrm{~d}, J=1.2 \mathrm{~Hz}, 1 \mathrm{H}), 8.47(\mathrm{~d}, J=31.2 \mathrm{~Hz}, 2 \mathrm{H}), 8.17(\mathrm{dd}, J=3.6,1.2 \mathrm{~Hz}$, $1 \mathrm{H}), 7.90-7.86(\mathrm{~m}, 2 \mathrm{H}), 7.76(\mathrm{t}, J=8.4 \mathrm{~Hz}, 1 \mathrm{H}) 7.62-7.57(\mathrm{~m}, 2 \mathrm{H}), 2.43(\mathrm{~s}, 3 \mathrm{H}) ;{ }^{13} \mathrm{C} \mathrm{NMR}$ (151 MHz, DMSO- $\left.d_{6}\right): \delta 197.95,160.17,147.56,142.59,139.93,138.31,136.96,134.86,133.87$, 132.41, 130.89, 129.42, 124.20, 27.26. EI/MS m/z (\%): $324.4[\mathrm{M}+\mathrm{H}]^{+}$; $\left[\mathrm{M}-\mathrm{COCH}_{3}\right]=280.1$. Analitically calculated for $\mathrm{C}_{17} \mathrm{H}_{13} \mathrm{~N}_{3} \mathrm{O}_{2} \mathrm{~S}$ : C, 63.14; H, 4.05; N, 12.99. Found: $\mathrm{C}, 63.19 ; \mathrm{H}$, $4.08 ; \mathrm{N}, 12.97$. 
Compound 5-(4-chlorophenyl)- $N$-(pyrazin-2-yl)thiophene-2-carboxamide (4d). Offwhite solid, MP $=249-251{ }^{\circ} \mathrm{C}(68 \%$ yield, $150 \mathrm{mg}) .{ }^{1} \mathrm{H}$ NMR $\left(600 \mathrm{MHz}\right.$, DMSO- $\left.d_{6}\right): \delta$ $11.25(\mathrm{~s}, 1 \mathrm{H}), 9.39(\mathrm{~s}, 1 \mathrm{H}), 8.47(\mathrm{~s}, 1 \mathrm{H}), 8.41(\mathrm{~d}, J=2.1 \mathrm{~Hz}, 1 \mathrm{H}), 8.25(\mathrm{~d}, J=3.8 \mathrm{~Hz}, 1 \mathrm{H})$, $7.77(\mathrm{~d}, J=8.3 \mathrm{~Hz}, 2 \mathrm{H}), 7.64(\mathrm{~d}, J=3.8 \mathrm{~Hz}, 1 \mathrm{H}), 7.51(\mathrm{~d}, J=8.3 \mathrm{~Hz}, 2 \mathrm{H}) ;{ }^{13} \mathrm{C}$ NMR $(151$ MHz, DMSO- $\left.d_{6}\right)$ : $\delta 160.16,148.74,148.15,142.50,139.94,139.89,137.84,137.32,133.40$, $131.94,130.77,129.23,128.38,127.53,125.36$. EI/MS m/z (\%): $316.8[\mathrm{M}+\mathrm{H}]^{+} ;[\mathrm{M}-\mathrm{Cl}]=280.1$. Analitically calculated for $\mathrm{C}_{15} \mathrm{H}_{10} \mathrm{ClN}_{3} \mathrm{OS}: \mathrm{C}, 57.05 ; \mathrm{H}, 3.19 ; \mathrm{N}, 13.31$. Found: $\mathrm{C}, 57.09 ; \mathrm{H}$, 3.23; N, 13.28 .

Compound 5-(3-chloro-4-fluorophenyl)- $\mathrm{N}$-(pyrazin-2-yl)thiophene-2-carboxamide (4e). Light yellow solid, $\mathrm{MP}=229-231{ }^{\circ} \mathrm{C}(50 \%$ yield, $116 \mathrm{mg}) .{ }^{1} \mathrm{H}$ NMR $(600 \mathrm{MHz}$, DMSO- $\left.d_{6}\right): \delta 11.27(\mathrm{~s}, 1 \mathrm{H}), 9.38(\mathrm{~s}, 1 \mathrm{H}), 8.48(\mathrm{~d}, J=1.6 \mathrm{~Hz}, 1 \mathrm{H}), 8.42(\mathrm{~d}, J=2.4 \mathrm{~Hz}, 1 \mathrm{H})$, $8.25(\mathrm{~d}, J=4.0 \mathrm{~Hz}, 1 \mathrm{H}), 8.01(\mathrm{dd}, J=6.9,2.1 \mathrm{~Hz}, 1 \mathrm{H}), 7.76(\mathrm{ddd}, J=8.4,4.4,2.3 \mathrm{~Hz}, 1 \mathrm{H})$, $7.68(\mathrm{~d}, J=4.0 \mathrm{~Hz}, 1 \mathrm{H}), 7.51(\mathrm{t}, J=8.9 \mathrm{~Hz}, 1 \mathrm{H}) ;{ }^{13} \mathrm{C}$ NMR $\left(151 \mathrm{MHz}, \mathrm{DMSO}-d_{6}\right): \delta 160.12$, $158.13,156.47,148.71,146.81,142.53,140.00,137.30,131.86,130.78,127.75,126.69,125.93$, 120.62, 117.83. EI/MS m/z (\%): $334.8[\mathrm{M}+\mathrm{H}]^{+} ;[\mathrm{M}-\mathrm{F}, \mathrm{Cl}]=279.3$. Analitically calculated for $\mathrm{C}_{15} \mathrm{H}_{9} \mathrm{ClFN}_{3} \mathrm{OS}: \mathrm{C}, 53.98 ; \mathrm{H}, 2.72 ; \mathrm{N}, 12.59$. Found: $\mathrm{C}, 54.05 ; \mathrm{H}, 2.73 ; \mathrm{N}, 12.56$.

Compound 5-(3,5-dimethylphenyl)- $N$-(pyrazin-2-yl)thiophene-2-carboxamide (4f). Light blue solid, $\mathrm{MP}=154-156{ }^{\circ} \mathrm{C}(62 \%$ yield, $135 \mathrm{mg}) .{ }^{1} \mathrm{H}$ NMR $\left(600 \mathrm{MHz}, \mathrm{DMSO}-d_{6}\right): \delta$ $11.18(\mathrm{~s}, 1 \mathrm{H}), 9.40(\mathrm{~s}, 1 \mathrm{H}), 8.44(\mathrm{~s}, 1 \mathrm{H}), 8.39(\mathrm{~s}, 1 \mathrm{H}), 8.23(\mathrm{~d}, J=3.8 \mathrm{~Hz}, 1 \mathrm{H}), 7.52(\mathrm{~d}, J=3.8 \mathrm{~Hz}$, $1 \mathrm{H}), 7.32(\mathrm{~s}, 2 \mathrm{H}), 6.97(\mathrm{~s}, 1 \mathrm{H}), 2.28(\mathrm{~s}, 6 \mathrm{H}) ;{ }^{13} \mathrm{C}$ NMR $\left(151 \mathrm{MHz}, \mathrm{DMSO}-d_{6}\right): \delta 160.26,150.11$, 148.83, 142.40, 139.76, 138.33, 137.24, 136.96, 136.05, 135.85, 132.66, 131.89, 130.29, 124.33, 123.55, 20.75. EI/MS $m / z(\%): 310.4[\mathrm{M}+\mathrm{H}]^{+} ;\left[\mathrm{M}-2 \mathrm{CH}_{3}\right]=279.1$. Analitically calculated for $\mathrm{C}_{17} \mathrm{H}_{15} \mathrm{~N}_{3} \mathrm{OS}: \mathrm{C}, 66.00 ; \mathrm{H}, 4.89 ; \mathrm{N}, 13.58$. Found: $\mathrm{C}, 66.06 ; \mathrm{H}, 4.92 ; \mathrm{N}, 13.55$.

Compound 5-(4-methoxyphenyl)- $\mathrm{N}$-(pyrazin-2-yl)thiophene-2-carboxamide (4g). Light brown solid, MP $=110-112{ }^{\circ} \mathrm{C}(57 \%$ yield, $125 \mathrm{mg}) .{ }^{1} \mathrm{H}$ NMR $\left(600 \mathrm{MHz}\right.$, DMSO- $\left.d_{6}\right): \delta 11.19$ $(\mathrm{s}, 1 \mathrm{H}), 9.33(\mathrm{~d}, J=1.8 \mathrm{~Hz}, 1 \mathrm{H}), 8.46(\mathrm{~d}, J=1.8 \mathrm{~Hz}, 1 \mathrm{H}), 8.41(\mathrm{~d}, J=2.4 \mathrm{~Hz}, 1 \mathrm{H}), 8.24-8.20$ $(\mathrm{m}, 2 \mathrm{H}), 7.66(\mathrm{~d}, J=8.4 \mathrm{~Hz}, 2 \mathrm{H}), 7.33(\mathrm{~d}, J=8.4 \mathrm{~Hz}, 2 \mathrm{H}), 2.50(\mathrm{~s}, 3 \mathrm{H}) ;{ }^{13} \mathrm{C}$ NMR $(151 \mathrm{MHz}$, DMSO- $d_{6}$ ): $\delta 160.23,158.85,148.89,147.99,142.38,139.81,138.32,137.18,135.49,132.18$, $130.39,127.47,113.17,53.93$. EI $/ \mathrm{MS} m / z(\%): 312.4[\mathrm{M}+\mathrm{H}]^{+} ;\left[\mathrm{M}-\mathrm{OCH}_{3}\right]=280.1$. Analitically calculated for $\mathrm{C}_{16} \mathrm{H}_{13} \mathrm{~N}_{3} \mathrm{O}_{2} \mathrm{~S}: \mathrm{C}, 61.72 ; \mathrm{H}, 4.21 ; \mathrm{N}, 13.50$. Found: $\mathrm{C}, 61.78 ; \mathrm{H}, 4.24 ; \mathrm{N}, 13.48$.

Compound methyl 4-(5-(pyrazin-2-ylcarbamoyl)thiophen-2-yl)benzoate (4h). Brown solid, $\mathrm{MP}=144-146{ }^{\circ} \mathrm{C}(46 \%$ yield, $110 \mathrm{mg}) .{ }^{1} \mathrm{H}$ NMR $\left(600 \mathrm{MHz}, \mathrm{DMSO}-d_{6}\right): \delta 11.21$ $(\mathrm{s}, 1 \mathrm{H}), 9.38(\mathrm{~d}, \mathrm{~J}=1.2 \mathrm{~Hz}, 1 \mathrm{H}), 8.48(\mathrm{~s}, 1 \mathrm{H}), 8.41(\mathrm{~d}, J=3.0 \mathrm{~Hz}, 1 \mathrm{H}), 8.26(\mathrm{~d}, J=4.8 \mathrm{~Hz}$, $1 \mathrm{H}), 7.94(\mathrm{~d}, J=4.8 \mathrm{~Hz}, 1 \mathrm{H}), 7.78(\mathrm{~d}, J=8.4 \mathrm{~Hz}, 2 \mathrm{H}), 7.24(\mathrm{~d}, J=8.4 \mathrm{~Hz}, 2 \mathrm{H}), 3.89(\mathrm{~s}, 3 \mathrm{H})$; ${ }^{13} \mathrm{C}$ NMR $\left(151 \mathrm{MHz}\right.$, DMSO- $\left.d_{6}\right)$ : $\delta 161.56,160.45,148.79,142.51,139.91,138.55,137.32$, 133.23, 131.47, 130.78, 129.99, 128.40, 127.72, 115.08, 53.81. EI/MS m/z (\%): $340.4[\mathrm{M}+\mathrm{H}]^{+}$; $\left[\mathrm{M}-\mathrm{COOCH}_{3}\right]=280.1$. Analitically calculated for $\mathrm{C}_{17} \mathrm{H}_{13} \mathrm{~N}_{3} \mathrm{O}_{3} \mathrm{~S}: \mathrm{C}, 60.17 ; \mathrm{H}, 3.86 ; \mathrm{N}, 12.38$. Found: C, 60.24; $\mathrm{H}, 3.90 ; \mathrm{N}, 12.35$.

Compound 5-(4-(methylthio)phenyl)- $\mathrm{N}$-(pyrazin-2-yl)thiophene-2-carboxamide (4i). Light brown solid, MP $=229-231{ }^{\circ} \mathrm{C}(52 \%$ yield, $120 \mathrm{mg}) .{ }^{1} \mathrm{H}$ NMR $\left(600 \mathrm{MHz}, \mathrm{DMSO}-d_{6}\right)$ : $\delta 11.22(\mathrm{~s}, 1 \mathrm{H}), 9.38(\mathrm{~d}, J=1.1 \mathrm{~Hz}, 1 \mathrm{H}), 8.48-8.47(\mathrm{~m}, 1 \mathrm{H}), 8.41(\mathrm{~d}, J=2.4 \mathrm{~Hz}, 1 \mathrm{H}), 8.24(\mathrm{~d}$, $J=4.0 \mathrm{~Hz}, 1 \mathrm{H}), 7.70(\mathrm{~d}, J=8.4 \mathrm{~Hz}, 2 \mathrm{H}), 7.60(\mathrm{~d}, J=4.0 \mathrm{~Hz}, 1 \mathrm{H}), 7.33(\mathrm{~d}, J=8.4 \mathrm{~Hz}, 2 \mathrm{H})$, $2.52(\mathrm{~s}, 3 \mathrm{H}) ;{ }^{13} \mathrm{C}$ NMR $\left(151 \mathrm{MHz}, \mathrm{DMSO}-d_{6}\right): \delta 160.25,149.40,148.82,142.52,139.87,139.54$, $137.29,136.78,132.00,129.27,126.28,126.23,124.33,14.43$. EI/MS m/z (\%): $328.4[\mathrm{M}+\mathrm{H}]^{+}$; $\left[\mathrm{M}-\mathrm{SCH}_{3}\right]=280.1$. Analitically calculated for $\mathrm{C}_{16} \mathrm{H}_{13} \mathrm{~N}_{3} \mathrm{OS}_{2}$ : C, 58.69; $\mathrm{H}, 4.00 ; \mathrm{N}, 12.83$. Found: $\mathrm{C}, 58.75 ; \mathrm{H}, 4.02 ; \mathrm{N}, 12.80$.

Compound 5-(3,5-difluorophenyl)- $N$-(pyrazin-2-yl)thiophene-2-carboxamide (4j). Brown solid, $\mathrm{MP}=239-241{ }^{\circ} \mathrm{C}(58 \%$ yield, $130 \mathrm{mg}) .{ }^{1} \mathrm{H}$ NMR $\left(600 \mathrm{MHz}, \mathrm{DMSO}-d_{6}\right): \delta 11.28(\mathrm{~s}$, $1 \mathrm{H}), 9.37(\mathrm{~d}, J=1.4 \mathrm{~Hz}, 1 \mathrm{H}), 8.47(\mathrm{dd}, J=2.4,1.6 \mathrm{~Hz}, 1 \mathrm{H}), 8.26(\mathrm{~d}, J=4.0 \mathrm{~Hz}, 1 \mathrm{H}), 7.76$ $(\mathrm{d}, J=4.0 \mathrm{~Hz}, 1 \mathrm{H}), 7.63-7.60(\mathrm{~m}, 1 \mathrm{H}), 7.52(\mathrm{dd}, J=8.4,1.9 \mathrm{~Hz}, 2 \mathrm{H}), 7.26(\mathrm{tt}, J=9.2 \mathrm{~Hz}$, $2.1 \mathrm{~Hz}, 1 \mathrm{H}) ;{ }^{13} \mathrm{C}$ NMR $\left(151 \mathrm{MHz}\right.$, DMSO- $\left.d_{6}\right): \delta 163.70,162.07,160.06,148.67,146.58,142.53$, $140.03,138.90,137.29,136.12,131.70,128.67,126.74,109.13,103.93$. EI/MS m/z (\%): 318.4 [M $+\mathrm{H}]^{+} ;[\mathrm{M}-2 \mathrm{~F}]=279.1$. Analitically calculated for $\mathrm{C}_{15} \mathrm{H}_{9} \mathrm{~F}_{2} \mathrm{~N}_{3} \mathrm{OS}: \mathrm{C}, 56.78 ; \mathrm{H}, 2.86 ; \mathrm{N}, 13.24$. Found: C, 56.88; H, 2.89; N, 13.20 . 
Compound 5'-chloro- $N$-(pyrazin-2-yl)-2,2'-bithiophene-5-carboxamide (4k). Off-white solid, MP = 180-182 ${ }^{\circ} \mathrm{C}(39 \%$ yield, $90 \mathrm{mg}) .{ }^{1} \mathrm{H}$ NMR $\left(600 \mathrm{MHz}, \mathrm{DMSO}-d_{6}\right): \delta 11.26(\mathrm{~s}, 1 \mathrm{H})$, $9.42(\mathrm{~d}, J=3.0 \mathrm{~Hz}, 1 \mathrm{H}), 8.49(\mathrm{~d}, J=1.8 \mathrm{~Hz}, 1 \mathrm{H}), 8.44(\mathrm{~d}, J=2.4 \mathrm{~Hz}, 1 \mathrm{H}), 8.28(\mathrm{~d}, J=4.2 \mathrm{~Hz}$, $1 \mathrm{H}), 7.52(\mathrm{~d}, J=4.2 \mathrm{~Hz}, 1 \mathrm{H}), 7.30(\mathrm{~d}, J=6.0 \mathrm{~Hz}, 1 \mathrm{H}), 7.12(\mathrm{~d}, J=6.0 \mathrm{~Hz}, 1 \mathrm{H}), 2.47(\mathrm{~s}, 3 \mathrm{H})$; ${ }^{13} \mathrm{C}$ NMR $\left(151 \mathrm{MHz}, \mathrm{DMSO}-d_{6}\right): \delta 160.22,148.76,147.63,143.45,141.95,141.14,138.07$, $136.97,134.24,129.84,128.46,126.32,124.84$. EI/MS $m / z(\%): 322.8[\mathrm{M}+\mathrm{H}]^{+} ;[\mathrm{M}-\mathrm{Cl}]=286.0$. Analitically calculated for $\mathrm{C}_{13} \mathrm{H}_{8} \mathrm{ClN}_{3} \mathrm{OS}_{2}$ : C, 48.52; $\mathrm{H}, 2.51 ; \mathrm{N}, 13.06$. Found: $\mathrm{C}, 48.58 ; \mathrm{H}$, 2.53; N, 13.00 .

Compound 5'-methyl-N-(pyrazin-2-yl)-2,2'-bithiophene-5-carboxamide (41). Brown solid, MP $=200-202{ }^{\circ} \mathrm{C}(43 \%$ yield, $96 \mathrm{mg}) .{ }^{1} \mathrm{H}$ NMR $\left(600 \mathrm{MHz}, \mathrm{DMSO}-d_{6}\right): \delta 11.21(\mathrm{~s}$, $1 \mathrm{H}), 9.37(\mathrm{~d}, J=1.4 \mathrm{~Hz}, 1 \mathrm{H}), 8.47(\mathrm{dd}, J=2.4,1.6 \mathrm{~Hz}, 1 \mathrm{H}), 8.41(\mathrm{~d}, J=2.5 \mathrm{~Hz}, 1 \mathrm{H}), 8.18$ $(\mathrm{d}, J=4.0 \mathrm{~Hz}, 1 \mathrm{H}), 7.30(\mathrm{dd}, J=9.1,3.8 \mathrm{~Hz}, 2 \mathrm{H}), 6.86-6.82(\mathrm{~m}, 1 \mathrm{H}), 2.47(\mathrm{~s}, 3 \mathrm{H}) ;{ }^{13} \mathrm{C} \mathrm{NMR}$ $\left(151 \mathrm{MHz}, \mathrm{DMSO}-d_{6}\right)$ : $\delta 160.11,148.77,143.29,142.51,141.00,139.87,137.25,135.99,133.15$, 131.86, 127.00, 125.82, 123.98, 14.97. EI/MS m/z (\%): $302.4[\mathrm{M}+\mathrm{H}]^{+} ;\left[\mathrm{M}-\mathrm{SCH}_{3}\right]=286.0$. Analitically calculated for $\mathrm{C}_{14} \mathrm{H}_{11} \mathrm{~N}_{3} \mathrm{OS}_{2}$ : C, 55.79; $\mathrm{H}, 3.68 ; \mathrm{N}, 13.94$. Found: $\mathrm{C}, 55.86 ; \mathrm{H}$, 3.63; N, 13.96.

Compound 5-(3,5-bis(trifluoromethyl)phenyl)-N-(pyrazin-2-yl)thiophene-2-carboxamide (4m). Brown solid, $\mathrm{MP}=203-205^{\circ} \mathrm{C}(48 \%$ yield, $140 \mathrm{mg}) .{ }^{1} \mathrm{H}$ NMR $\left(600 \mathrm{MHz}, \mathrm{DMSO}-d_{6}\right)$ : $\delta 11.28(\mathrm{~s}, 1 \mathrm{H}), 9.09(\mathrm{~s}, 1 \mathrm{H}), 8.61(\mathrm{~s}, 1 \mathrm{H}), 8.49-8.45(\mathrm{~m}, 2 \mathrm{H}), 8.278 .02(\mathrm{~d}, J=1.8 \mathrm{~Hz}, 2 \mathrm{H}), 8.13$ $7.89(\mathrm{~d}, J=8.4 \mathrm{~Hz}, 1 \mathrm{H}), 8.107 .71(\mathrm{~d}, J=8.4 \mathrm{~Hz}, 1 \mathrm{H}) ;{ }^{13} \mathrm{C}$ NMR $\left(151 \mathrm{MHz}, \mathrm{DMSO}-d_{6}\right): \delta$ $160.18,148.73,147.05,142.49,139.93,138.29,134.47,134.01,133.86,132.41,130.19,129.03$, 125.93, 119.97. EI/MS m/z (\%): $418.4[\mathrm{M}+\mathrm{H}]^{+} ;[\mathrm{M}-6 \mathrm{~F}]=303.1$. Analitically calculated for $\mathrm{C}_{17} \mathrm{H}_{9} \mathrm{~F}_{6} \mathrm{~N}_{3} \mathrm{OS}: \mathrm{C}, 48.93 ; \mathrm{H}, 2.17 ; \mathrm{N}, 10.07$. Found: $\mathrm{C}, 48.99 ; \mathrm{H}, 2.19 ; \mathrm{N}, 10.11$.

Compound 5-(3-chloro-5-(trifluoromethyl)phenyl)- $N$-(pyrazin-2-yl)thiophene-2-carboxamide (4n). Brown solid, $\mathrm{MP}=170-172{ }^{\circ} \mathrm{C}(37 \%$ yield, $100 \mathrm{mg}) .{ }^{1} \mathrm{H}$ NMR $(600$ $\left.\mathrm{MHz}, \mathrm{DMSO}-d_{6}\right): \delta 11.24(\mathrm{~s}, 1 \mathrm{H}), 9.13(\mathrm{~s}, 1 \mathrm{H}), 8.54-8.48(\mathrm{~m}, 3 \mathrm{H}), 8.04-8.00(\mathrm{~m}, 2 \mathrm{H}), 7.85$ $(\mathrm{d}, J=7.8 \mathrm{~Hz}, 1 \mathrm{H}), 8.017 .66(\mathrm{~d}, J=7.8 \mathrm{~Hz}, 1 \mathrm{H}) ;{ }^{13} \mathrm{C}$ NMR $\left(151 \mathrm{MHz}, \mathrm{DMSO}-d_{6}\right): \delta 160.16$, $148.77,147.76,142.51,139.89,138.31,137.29,135.41,134.89,134.06,132.21,130.43,129.23$, 124.87, 119.93. EI/MS m/z (\%): $384.8[\mathrm{M}+\mathrm{H}]^{+} ;[\mathrm{M}-3 \mathrm{~F}]=326.0,[\mathrm{M}-\mathrm{Cl}]=348.0$. Analitically calculated for $\mathrm{C}_{16} \mathrm{H}_{9} \mathrm{ClF}_{3} \mathrm{~N}_{3} \mathrm{OS}$ : C, 50.07; $\mathrm{H}, 2.36 ; \mathrm{N}, 10.95$. Found: $\mathrm{C}, 50.15 ; \mathrm{H}, 2.38 ; \mathrm{N}$, 10.89 .

\section{Conclusions}

In this study, 5-bromo- $N$-(pyrazin-2-yl)thiophene-2-carboxamide (3) was synthesized by means of $\mathrm{TiCl}_{4}$-mediated one-pot condensation of pyrazin-2-amine (1) and 5bromothiophene-2-carboxylic acid (2) with a good 75\% yield followed by a Suzuki crosscoupling reaction with various aryl/heteroaryl boronic acids/pinacol esters to synthesize 5-aryl-N-(pyrazin-2-yl)thiophene-2-carboxamides (4a-4n) obtained with moderate and good yields (37-72\%). The target pyrazine analogs (4a-4n) were confirmed by NMR and mass spectrometry. The computational studies of these final compounds were also performed to get optimized geometries and thermodynamic parameters such as FMOs ( $\left.\mathrm{E}_{\mathrm{HOMO}}, \mathrm{E}_{\mathrm{LUMO}}\right), \mathrm{HOMO}-\mathrm{LUMO}$ energy gap, electron affinity (A), ionization energy (I), electrophilicity index $(\omega)$, chemical softness $(\sigma)$ and chemical hardness $(\eta)$. The stability and NLO behavior of all the compounds $4 \mathbf{a}-4 \mathbf{n}$ were studied with the help of the HOMOLUMO energy gap and hyperpolarizability calculations. Compound $4 \mathbf{i}$ was found to be the most reactive compound with the highest electronic chemical potential value $(-3.88 \mathrm{eV})$ and compound 41 had the highest hyperpolarizability value of 8583.80 Hartrees. The theoretical calculated chemical shifts of ${ }^{1} \mathrm{H}$ NMR of all compounds $4 \mathbf{a}-\mathbf{4 n}$ match very well the experimental values.

Supplementary Materials: The following are available online. Theoratical ${ }^{1} \mathrm{HNMR}$ (Tables S1-S13), the ${ }^{1} \mathrm{HNMR}$ and ${ }^{13} \mathrm{CNMR}$ (Figures S1-S17), Potential energy Scan (Figures S18-S30) and lowest energy conformers are available online. 
Author Contributions: Conceptualization, N.R. and G.A.; methodology, G.A., M.S.A. and N.R.; experiments, G.A.; software, A.M. and M.A.H.; formal analysis, G.A., A.M., M.A.H., M.S.A. and M.B.; investigation, G.A., N.R., S.H. and M.Z.; writing-original draft preparation M.B., S.H., G.A. and A.M.; writing-review and editing, G.A., N.R., M.H., M.A.H., S.H. and M.B.; supervision, N.R.; project administration, N.R. and A.F.Z.; funding acquisition, M.S.A. All authors have read and agreed to the published version of the manuscript.

Funding: The authors sincerely appreciate funding from the Researchers Supporting Project number (RSP-2021/399), King Saud University, Riyadh, Saudi Arabia.

Institutional Review Board Statement: Not applicable.

Informed Consent Statement: Not applicable.

Data Availability Statement: Data are contained within the article and the Supplementary Materials.

Conflicts of Interest: The authors declare no conflict of interest.

Sample Availability: Not applicable.

\section{References}

1. Dubuisson, M.; Rees, J.-F.; Marchand-Brynaert, J. Discovery and validation of a new family of antioxidants: The aminopyrazine derivatives. Mini Rev. Med. Chem. 2004, 4, 421-435. [CrossRef]

2. Higasio, Y.S.; Shoji, T. Heterocyclic compounds such as pyrroles, pyridines, pyrollidins, piperdines, indoles, imidazol and pyrazins. Appl. Catal. A 2001, 221, 197-207. [CrossRef]

3. Kamal, A.; Reddy, J.S.; Ramaiah, M.J.; Dastagiri, D.; Bharathi, E.V.; Sagar, M.V.P.; Pushpavalli, S.; Ray, P.; Pal-Bhadra, M. Design, synthesis and biological evaluation of imidazopyridine/pyrimidine-chalcone derivatives as potential anticancer agents. MedChem Comm 2010, 1, 355-360. [CrossRef]

4. Ghosh, P.; Rasul, M.; Chakraborty, M.; Mandal, A.; Saha, A. Microwave assisted one-pot synthesis of pyrazine derivatives of pentacyclic triterpenoids and their biological activity. Indian J. Chem. 2011, 50B, 1519-1523. [CrossRef]

5. Meher, C.; Rao, A.; Omar, M. Piperazine-pyrazine and their multiple biological activities. Asian J. Pharm. Sci. 2013, 3, 43-60.

6. Bonde, C.G.; Gaikwad, N.J. Synthesis and preliminary evaluation of some pyrazine containing thiazolines and thiazolidinones as antimicrobial agents. Bioorg. Med. Chem. 2004, 12, 2151-2161. [CrossRef] [PubMed]

7. Sriram, D.; Yogeeswari, P.; Reddy, S.P. Synthesis of pyrazinamide Mannich bases and its antitubercular properties. Bioorg. Med. Chem. Lett. 2006, 16, 2113-2116. [CrossRef]

8. Vergara, F.M.; Lima, C.H.d.S.; das Graças M. de O. Henriques, M.; Candéa, A.L.; Lourenço, M.C.; Ferreira, M.d.L.; Kaiser, C.R.; de Souza, M.V. Synthesis and antimycobacterial activity of $\mathrm{N}^{\prime}$-[(E)-(monosubstituted-benzylidene)]-2-pyrazinecarbohydrazide derivatives. Eur. J. Med. Chem. 2009, 44, 4954-4959. [CrossRef] [PubMed]

9. Abdel-Aziz, M.; Abdel-Rahman, H.M. Synthesis and anti-mycobacterial evaluation of some pyrazine-2-carboxylic acid hydrazide derivatives. Eur. J. Med. Chem. 2010, 45, 3384-3388. [CrossRef] [PubMed]

10. Czerny, M.; Mayer, F.; Grosch, W. Sensory study on the character impact odorants of roasted Arabica coffee. J. Agric. Food Chem. 1999, 47, 695-699. [CrossRef]

11. Cai, L.; Sun, Y.; Song, Y.; Xu, L.; Bei, Z.; Zhang, D.; Dou, Y.; Wang, H. Viral polymerase inhibitors T-705 and T-1105 are potential inhibitors of Zika virus replication. Arch. Virol. 2017, 162, 2847-2853. [CrossRef] [PubMed]

12. Furuta, Y.; Takahashi, K.; Shiraki, K.; Sakamoto, K.; Smee, D.F.; Barnard, D.L.; Gowen, B.B.; Julander, J.G.; Morrey, J.D. T-705 (favipiravir) and related compounds: Novel broad-spectrum inhibitors of RNA viral infections. Antivir. Res. 2009, 82, 95-102. [CrossRef]

13. Baranovich, T.; Wong, S.-S.; Armstrong, J.; Marjuki, H.; Webby, R.J.; Webster, R.G.; Govorkova, E.A. T-705 (favipiravir) induces lethal mutagenesis in influenza A H1N1 viruses in vitro. J. Virol. 2013, 87, 3741-3751. [CrossRef]

14. Du, Y.X.; Chen, X.P. Favipiravir: Pharmacokinetics and concerns about clinical trials for 2019-nCoV infection. Clin. Pharmacol. Ther. 2020, 108, 242-247. [CrossRef]

15. Mallesha, L.; Mohana, K.N. Synthesis, antimicrobial and antioxidant activities of 1-(1,4-benzodioxane-2-carbonyl) piperazine derivatives. Eur. J. Chem. 2011, 2, 193-199. [CrossRef]

16. Dolezal, M.; Zitko, J.; Osicka, Z.; Kunes, J.; Vejsova, M.; Buchta, V.; Dohnal, J.; Jampilek, J.; Kralova, K. Synthesis, antimycobacterial, antifungal and photosynthesis-inhibiting activity of chlorinated N-phenylpyrazine-2-carboxamides. Molecules 2010, 15, 8567-8581. [CrossRef]

17. Satoskar, R.S.; Bhandarkar, S. Pharmacology and Pharmacotherapeutics; Elsevier India: Kolkata, India, 2020.

18. Zhang, Y.; Wade, M.M.; Scorpio, A.; Zhang, H.; Sun, Z. Mode of action of pyrazinamide: Disruption of Mycobacterium tuberculosis membrane transport and energetics by pyrazinoic acid. J. Antimicrob. Chemother. 2003, 52, 790-795. [CrossRef]

19. Dorn, R.; Baums, D.; Kersten, P.; Regener, R. Nonlinear optical materials for integrated optics: Telecommunications and sensors. Adv. Mater. 1992, 4, 464-473. [CrossRef] 
20. Marder, S.R.; Perry, J.W. Molecular materials for second-order nonlinear optical applications. Adv. Mater. 1993, 5, 804-815. [CrossRef]

21. Dini, D.; Calvete, M.J.; Hanack, M. Nonlinear optical materials for the smart filtering of optical radiation. Chem. Rev. 2016, 116, 13043-13233. [CrossRef] [PubMed]

22. Liu, J.; Ouyang, C.; Huo, F.; He, W.; Cao, A. Progress in the enhancement of electro-optic coefficients and orientation stability for organic second-order nonlinear optical materials. Dyes Pigments 2020, 181, 108509. [CrossRef]

23. Bureš, F. Fundamental aspects of property tuning in push-pull molecules. RSC Adv. 2014, 4, 58826-58851. [CrossRef]

24. Meti, P.; Park, H.-H.; Gong, Y.-D. Recent developments in pyrazine functionalized $\pi$-conjugated materials for optoelectronic applications. J. Mater. Chem. C 2020, 8, 352-379. [CrossRef]

25. Achelle, S.; Baudequin, C.; Plé, N. Luminescent materials incorporating pyrazine or quinoxaline moieties. Dyes Pigments 2013, 98, 575-600. [CrossRef]

26. Hebbar, N.; Ramondenc, Y.; Plé, G.; Dupas, G.; Plé, N. Push-pull structures with a pyrazine core and hexatriene chain: Synthesis and light-emitting properties. Tetrahedron 2009, 65, 4190-4200. [CrossRef]

27. Coe, B.J.; Fielden, J.; Foxon, S.P.; Asselberghs, I.; Clays, K.; Brunschwig, B.S. Two-dimensional, pyrazine-based nonlinear optical chromophores with ruthenium (II) ammine electron donors. Inorg. Chem. 2010, 49, 10718-10726. [CrossRef]

28. Dokládalová, L.; Bureš, F.; Kuznik, W.; Kityk, I.V.; Wojciechowski, A.; Mikysek, T.; Almonasy, N.; Ramaiyan, M.; Padělková, Z.; Kulhánek, J. Dicyanobenzene and dicyanopyrazine derived X-shaped charge-transfer chromophores: Comparative and structure-property relationship study. Org. Biomol. Chem. 2014, 12, 5517-5527. [CrossRef]

29. Sun, Y.; Liu, X.T.; Guo, J.F.; Ren, A.M.; Wang, D. Theoretical investigation of two-photon absorption and fluorescence properties of cypridina luciferin-based derivatives: 2, 3, 5-trisubstituted pyrazine compounds. J. Phys. Org. Chem. 2013, 26, 822-833. [CrossRef]

30. Li, H.; Zhang, Y.; Bi, Z.; Xu, R.; Li, M.; Shen, X.; Tang, G.; Han, K. Theoretical study on the spectroscopic and third-order nonlinear optical properties of two-dimensional charge-transfer pyrazine derivatives. Mol. Phys. 2017, 115, 3164-3171. [CrossRef]

31. Chen, M.; Nie, H.; Song, B.; Li, L.; Sun, J.Z.; Qin, A.; Tang, B.Z. Triphenylamine-functionalized tetraphenylpyrazine: Facile preparation and multifaceted functionalities. J. Mater. Chem. C 2016, 4, 2901-2908. [CrossRef]

32. Imran, H.M.; Rasool, N.; Kanwal, I.; Hashmi, M.A.; Altaf, A.A.; Ahmed, G.; Malik, A.; Kausar, S.; Khan, S.U.-D.; Ahmad, A. Synthesis of halogenated $\left[1,1^{\prime}\right.$-biphenyl]-4-yl benzoate and $\left[1,1^{\prime}: 3^{\prime}, 1^{\prime \prime}\right.$-terphenyl]-4'-yl benzoate by palladium catalyzed cascade C-C coupling and structural analysis through computational approach. J. Mol. Struct. 2020, 1222, 1-9. [CrossRef]

33. Lewars, E. Introduction to the theory and applications of molecular and quantum mechanics. In Computational Chemistry; Springer: Berlin, Germany, 2003; Volume 318.

34. Malik, A.; Rasool, N.; Kanwal, I.; Hashmi, M.A.; Zahoor, A.F.; Ahmad, G.; Altaf, A.A.; Shah, S.A.A.; Sultan, S.; Zakaria, Z.A. Suzuki-miyaura reactions of (4-bromophenyl)-4,6-dichloropyrimidine through commercially available palladium catalyst: Synthesis, optimization and their structural aspects identification through computational studies. Processes 2020, $8,1342$. [CrossRef]

35. Marenich, A.V.; Cramer, C.J.; Truhlar, D.G. Universal solvation model based on solute electron density and on a continuum model of the solvent defined by the bulk dielectric constant and atomic surface tensions. J. Phys. Chem. B 2009, 113, 6378-6396. [CrossRef] [PubMed]

36. Dennington, R.; Keith, T.A.; Millam, J.M. GaussView 6.0.16; Semichem Inc.: Shawnee Mission, KS, USA, 2016.

37. Frisch, M.J.; Trucks, G.W.; Schlegel, H.B.; Scuseria, G.E.; Robb, M.A.; Cheeseman, J.R.; Scalmani, G.; Barone, V.; Mennucci, B.; Petersson, G.A.; et al. Gaussian 09 Revision D. 01; Gaussian Inc.: Wallingford, CT, USA, 2010.

38. Schlegel, H.B. Geometry optimization. Wiley Interdiscip. Rev. Comput. Mol. Sci. 2011, 1, 790-809. [CrossRef]

39. Singh, R.K.; Singh, A.K.; Siddiqui, S.; Arshad, M.; Jafri, A. Synthesis, molecular structure, spectral analysis and cytotoxic activity of two new aroylhydrazones. J. Mol. Struct. 2017, 1135, 82-97. [CrossRef]

40. Gökce, H.; Öztürk, N.; Kazıc1, M.; Göreci, Ç.Y.; Güneş, S. Structural, spectroscopic, electronic, nonlinear optical and thermodynamic properties of a synthesized Schiff base compound: A combined experimental and theoretical approach. J. Mol. Struct. 2017, 1136, 288-302. [CrossRef]

41. Kanaani, A.; Ajloo, D.; Grivani, G.; Ghavami, A.; Vakili, M. Tautomeric stability, molecular structure, NBO, electronic and NMR analyses of salicylideneimino-ethylimino-pentan-2-one. J. Mol. Struct. 2016, 1112, 87-96. [CrossRef]

42. O'Brien, S.E.; Browne, H.L.; Bradshaw, T.D.; Westwell, A.D.; Stevens, M.F.; Laughton, C.A. Antitumor benzothiazoles. Frontier molecular orbital analysis predicts bioactivation of 2-(4-aminophenyl) benzothiazoles to reactive intermediates by cytochrome P4501A1. Org. Biomol. Chem. 2003, 1, 493-497. [CrossRef]

43. Arshad, M.N.; Bibi, A.; Mahmood, T.; Asiri, A.M.; Ayub, K. Synthesis, crystal structures and spectroscopic properties of triazine-based hydrazone derivatives; a comparative experimental-theoretical study. Molecules 2015, 20, 5851-5874. [CrossRef]

44. Belletête, M.; Beaupré, S.; Bouchard, J.; Blondin, P.; Leclerc, M.; Durocher, G. Theoretical and experimental investigations of the spectroscopic and photophysical properties of fluorene-phenylene and fluorene-thiophene derivatives: Precursors of light-emitting polymers. J. Phys. Chem. B 2000, 104, 9118-9125. [CrossRef]

45. Peng, W.; Peiwang, Z.; Chuanguang, W.; Cheng, Y. Theoretical investigation and molecular design of pyrazine derivatives with large hyperpolarizabilities ( $\beta$ ). J. Mol. Struct. Theor. Chem 1999, 459, 155-162. [CrossRef]

46. Ceylan, Ü.; Tarı, G.Ö.; Gökce, H.; Ağar, E. Spectroscopic (FT-IR and UV-Vis) and theoretical (HF and DFT) investigation of 2-Ethyl-N-[(5-nitrothiophene-2-yl) methylidene] aniline. J. Mol. Struct. 2016, 1110, 1-10. [CrossRef] 
47. Mathammal, R.; Sangeetha, K.; Sangeetha, M.; Mekala, R.; Gadheeja, S. Molecular structure, vibrational, UV, NMR, HOMOLUMO, MEP, NLO, NBO analysis of 3, 5 di tert butyl 4 hydroxy benzoic acid. J. Mol. Struct. 2016, 1120, 1-14. [CrossRef]

48. Politzer, P.; Murray, J.S. The fundamental nature and role of the electrostatic potential in atoms and molecules. Theor. Chem. Acc. 2002, 108, 134-142. [CrossRef]

49. Tsuneda, T.; Song, J.-W.; Suzuki, S.; Hirao, K. On Koopmans' theorem in density functional theory. J. Chem. Phys. 2010, 133, 174101. [CrossRef]

50. Guo, L.; Safi, Z.S.; Kaya, S.; Shi, W.; Tüzün, B.; Altunay, N.; Kaya, C. Anticorrosive effects of some thiophene derivatives against the corrosion of iron: A computational study. Front. Chem. 2018, 6, 155. [CrossRef] [PubMed]

51. Martínez, J. Local reactivity descriptors from degenerate frontier molecular orbitals. Chem. Phys. Lett. 2009, 478, 310-322. [CrossRef]

52. Mubarik, A.; Rasool, N.; Hashmi, M.A.; Mansha, A.; Zubair, M.; Shaik, M.R.; Sharaf, M.A.; Awwad, E.M.; Abdelgawad, A. Computational Study of Structural, Molecular Orbitals, Optical and Thermodynamic Parameters of Thiophene Sulfonamide Derivatives. Crystals 2021, 11, 211. [CrossRef]

53. Leggio, A.; Bagalà, J.; Belsito, E.L.; Comandè, A.; Greco, M.; Liguori, A. Formation of amides: One-pot condensation of carboxylic acids and amines mediated by $\mathrm{TiCl}_{4}$. Chem. Cent. J. 2017, 11, 87-98. [CrossRef]

54. Ahmad, G.; Rasool, N.; Rizwan, K.; Imran, I.; Zahoor, A.F.; Zubair, M.; Sadiq, A.; Rashid, U. Synthesis, in-vitro cholinesterase inhibition, in-vivo anticonvulsant activity and in-silico exploration of N-(4-methylpyridin-2-yl) thiophene-2-carboxamide analogs. Bioorg. Chem. 2019, 92, 103216. [CrossRef]

55. Miyaura, N.; Suzuki, A. Palladium-catalyzed cross-coupling reactions of organoboron compounds. Chem. Rev. 1995, 95, 2457-2483. [CrossRef]

56. Ahmad, G.; Rasool, N.; Ikram, H.M.; Gul Khan, S.; Mahmood, T.; Ayub, K.; Zubair, M.; Al-Zahrani, E.; Ali Rana, U.; Akhtar, M.N. Efficient synthesis of novel pyridine-based derivatives via Suzuki cross-coupling reaction of commercially available 5bromo-2-methylpyridin-3-amine: Quantum mechanical investigations and biological activities. Molecules 2017, 22, 190. [CrossRef] [PubMed]

57. Ikram, H.; Rasool, N.; Ahmad, G.; Chotana, G.; Musharraf, S.; Zubair, M.; Rana, U.; Haq, M.Z.U.; Jaafar, H. Selective C-arylation of 2, 5-dibromo-3-hexylthiophene via suzuki cross coupling reaction and their pharmacological aspects. Molecules 2015, 20, 5202-5214. [CrossRef] [PubMed]

58. Ahmad, G.; Rasool, N.; Rizwan, K.; Altaf, A.A.; Rashid, U.; Mahmood, T.; Ayub, K. Role of Pyridine Nitrogen in PalladiumCatalyzed Imine Hydrolysis: A Case Study of (E)-1-(3-bromothiophen-2-yl)-N-(4-methylpyridin-2-yl) methanimine. Molecules 2019, 24, 2609. [CrossRef] [PubMed]

59. Ahmad, G.; Rasool, N.; Qamar, M.U.; Alam, M.M.; Kosar, N.; Mahmood, T.; Imran, M. Facile synthesis of 4-aryl-N-(5-methyl-1Hpyrazol-3-yl) benzamides via Suzuki Miyaura reaction: Antibacterial activity against clinically isolated NDM-1-positive bacteria and their Docking Studies. Arab. J. Chem. 2021, 14, 1-11. [CrossRef]

60. Mahmood, N.; Rasool, N.; Ikram, H.M.; Hashmi, M.A.; Mahmood, T.; Zubair, M.; Ahmad, G.; Rizwan, K.; Rashid, T.; Rashid, U. Synthesis of 3, 4-Biaryl-2, 5-Dichlorothiophene through Suzuki Cross-Coupling and Theoretical Exploration of Their Potential Applications as Nonlinear Optical Materials. Symmetry 2018, 10, 766. [CrossRef]

61. Rizwan, K.; Rasool, N.; Rehman, R.; Mahmood, T.; Ayub, K.; Rasheed, T.; Ahmad, G.; Malik, A.; Khan, S.A.; Akhtar, M.N. Facile synthesis of N-(4-bromophenyl)-1-(3-bromothiophen-2-yl) methanimine derivatives via Suzuki cross-coupling reaction: Their characterization and DFT studies. Chem. Cent. J. 2018, 12, 84-92. [CrossRef] [PubMed]

62. Ikram, H.M.; Rasool, N.; Hashmi, M.A.; Anjum, M.A.; Ali, K.G.; Zubair, M.; Ahmad, G.; Mahmood, T. Density functional theory-supported studies of structural and electronic properties of substituted-phenol derivatives synthesized by efficient O-or C-arylation via Chan-Lam or Suzuki cross-coupling reactions. Turk. J. Chem. 2019, 43, 1306-1321. [CrossRef]

63. Abbas, M.; Rizwan, K.; Rasool, N.; Hashmi, M.A.; Ahmad, G.; Rashid, U.; Shah, S.A.A. Palladium (0) catalyzed synthesis of thiophene based 1, 3, 4-oxadiazoles their reactivities and potential nonlinear optical properties. Chiang Mai J. Sci. 2020, 47, $1255-1264$. 